Research Article

\title{
Current trend of bacteriological sensitivity patterns from superficial and deep wounds in pressure ulcers
}

\author{
Ajay Lunawat*, Rishi Kant Vashistha, Himanshu Patidar, Vishad Patel
}

Department of Surgery, Sri Aurobindo Medical College and PG Institute, Indore, Madhya Pradesh, India

Received: 05 April 2016

Accepted: 10 May 2016

*Correspondence:

Dr. Ajay Lunawat,

E-mail: drajay_lunawat@rediffmail.com

Copyright: ( ) the author(s), publisher and licensee Medip Academy. This is an open-access article distributed under the terms of the Creative Commons Attribution Non-Commercial License, which permits unrestricted non-commercial use, distribution, and reproduction in any medium, provided the original work is properly cited.

\section{ABSTRACT}

Background: To investigate the incidence of different bacteria isolates in 50 samples of superficial pus culture and deep tissue specimen from pressure ulcer in a tertiary health care centre in central India and their antibacterial susceptibility patterns.

Methods: Wound swab and tissue samples were collected from grade III/grade IV pressure ulcer and cultured for bacterial isolates. The isolates were characterized and identified by standard microbiological methods. Antibiotic susceptibility testing was carried out.

Results: Out of 50 specimens of superficial pus culture, $98 \%$ were infected with bacteria. Predominant isolate was of staphylococcus aureus (42\%), pseudomonas (28\%), streptococcus (18\%) and E. coli (14\%). Deep tissue culture of same specimens showed that there was no growth in 17 (34\%) specimen. Pseudomonas was isolated in $14(28 \%)$ and Klebsiella in $9(18 \%)$.

Conclusions: We suggest a multidisciplinary approach to wound management, routine microbiological surveillance of wounds, rational drug use and the institution of strong infection control policies.

Keywords: Wound, Staphylococcus aureus, Streptococcus, Pseudomonas, E. coli

\section{INTRODUCTION}

Pressure ulcers have affected humans for ages, and addressing the overall management of pressure ulcers is now a prominent national healthcare issue. Pressure ulcers have important consequences both for patients and for the health care system. They can lead to severe or intolerable pain, are prone to infection, and are associated with high mortality rates. ${ }^{1}$

Pressure ulcers, also known as decubitus ulcers or bedsores, are localized injuries to the skin and/or underlying tissue that usually occur over a bony prominence as a result of pressure, or pressure in combination with shear and/or friction.
The most common sites are the sacrum, coccyx, heels or the hips, but other sites such as the elbows, knees, ankles or the occiput can also be affected.

Normal function of intact skin is to control microbial population that live on the skin surface and to prevent underlying tissue from becoming colonized and invaded by potential pathogens. Exposure of subcutaneous tissue following a loss of skin integrity (i.e in pressure ulcer) provides a moist, warm and nutritious environment that is conducive to microbial colonization and proliferation. However the abundance and diversity of micro-organism in any wound will be influenced by factors such as wound type, depth, location, quality, level of tissue perfusion and the host immune response. 
Since wound colonization is most frequently polymicrobial involving numerous micro-organism that are potentially pathogenic, any pressure ulcer is at some risk of becoming infected. In the event of infection, an ulcer fails to heal, the patient suffers increased trauma, treatment cost rises and management becomes more resource demanding.

Table 1: Pressure ulcer staging. ${ }^{2}$

\begin{tabular}{|c|c|}
\hline Stage 1 & $\begin{array}{l}\text { Intact skin with non-blanchable } \\
\text { redness of a localized area usually } \\
\text { over a bony prominence }\end{array}$ \\
\hline Stage 2 & $\begin{array}{l}\text { Partial thickness loss of dermis } \\
\text { presenting as a shallow open ulcer with } \\
\text { a red pink wound bed, without slough }\end{array}$ \\
\hline Stage 3 & $\begin{array}{l}\text { Full thickness tissue loss. } \\
\text { Subcutaneous fat may be visible but } \\
\text { bone, tendon or muscles are not } \\
\text { exposed. Slough may be present but } \\
\text { does not obscure the depth of tissue } \\
\text { loss. May include undermining and } \\
\text { tunnelling. The depth of a } \\
\text { category/stage III pressure ulcer varies } \\
\text { by anatomical location. }\end{array}$ \\
\hline Stage 4 & $\begin{array}{l}\text { Full thickness tissue loss with exposed } \\
\text { bone, tendon or muscle. Slough or } \\
\text { eschar may be present. Often includes } \\
\text { undermining and tunnelling. The depth } \\
\text { of a category /stage IV pressure ulcer } \\
\text { varies by anatomical location. }\end{array}$ \\
\hline $\begin{array}{l}\text { Unstageable } \\
\text { /unclassified }\end{array}$ & $\begin{array}{l}\text { Full thickness tissue loss in which } \\
\text { actual depth of the ulcer is completely } \\
\text { obscured by slough (yellow, tan, gray, } \\
\text { green or brown) and/or eschar (tan, } \\
\text { brown or black) in the wound bed. }\end{array}$ \\
\hline $\begin{array}{l}\text { Suspected } \\
\text { deep tissue } \\
\text { injury }\end{array}$ & $\begin{array}{l}\text { Purple or maroon localized area of } \\
\text { discoloured intact skin or blood-filled } \\
\text { blister due to damage of underlying } \\
\text { soft tissue from pressure and/or shear. } \\
\text { The area may be preceded by tissue } \\
\text { that is painful, firm, mushy, boggy, } \\
\text { warmer or cooler as compared to } \\
\text { adjacent tissue. Deep tissue injury may } \\
\text { be difficult to detect in individuals with } \\
\text { dark skin tones. }\end{array}$ \\
\hline
\end{tabular}

Thus whether an ulcer/wound should be sampled for culture and sensitivity or not? If yes, then whether a superficial swab or deep tissue culture should be done? What is the justification of doing a deep tissue culture when a simple swab on a gram staining can give enough information?

Culture sensitivity of these pressure ulcers are important as they guide in the treatment of the infected pressure ulcers and the proper use of antibiotics are helpful in preventing the development of resistance to antibiotics.
Antibiotic resistance is a serious problem that has the potential to drag the world into pre-antibiotic era. The most probable reason is the widespread use of antibiotics and often choosing an inappropriate drug. The misuse of antibiotics stems primarily from the inherent inclination of doctors toward prescribing the potent antibiotics. As one expert puts it, "when it comes to prescribing antibiotics, most doctors use the canon, when a gun can be used to kill the same enemy". There is a need of periodic analysis of the pattern and sensitivity of organisms isolated and the results need to be communicated to doctors. The present study is one such effort to determine the profile and the antimicrobial sensitivity pattern of the frequently isolated bacteria from various cultures in a tertiary care hospital.

Following study was undertaken to evaluate efficacy of superficial swab and deep tissue culture/find out causative pathogens, their susceptibility and resistance to various antimicrobial agents used commonly all over the country.

\section{METHODS}

This study was conducted in department of general surgery, Sri Aurobindo Medical College and PG institute, Indore which is a tertiary health care center in Central India. Patients were enrolled after obtaining informed consent from them or their attendants.

The design of this study was a hospital based prospective study of 50 patients with pressure ulcers grade 3/grade 4 admitted in between $1^{\text {st }}$ January 2013 to $30^{\text {th }}$ September 2014 , conducted on the basis of data collected.

\section{Inclusion criteria}

All Patients getting admitted at Sri Aurobindo Medical College and PG Institute with pressure ulcers of grade 3/grade 4 consenting to be a part of study.

Patient should not have taken antibiotics in last one week.

\section{Exclusion criteria}

All those patients with pressure sores grade 1 and grade 2. A sample of pus was collected on a sterile swab after cleaning of the lesions with normal saline. A sample of tissue was collected from the floor of the pressure ulcer and sent in a sterile container.

Swab is used to a make a thin smear on a clean glass slide and then swab was sent for culture and susceptibility studies. Similarly, a thin smear is made from tissue specimen also and then tissue is sent for culture and susceptibility studies.

The pus was inoculated on blood agar and Mac conkeys agar and incubated at $37^{\circ} \mathrm{C}$ for 24 hours and further for 48 hours if necessary, the organisms grown were 
identified on basis of their morphology, cultural characters and biochemical reactions according to standard procedures. Tissue specimens need to be crushed and then the pieces are inoculated on the culture media.

The antibiotic susceptibility testing was performed by Kirby Bauer disc diffusion method and the interpretations were made using CLSI (clinical and laboratory standards institute) guidelines 2013-14. Antibiotics used were ampicillin, amikacin, cefepime, cephotaxime, ceftazidime, levofloxacin, amoxicillin+sulbactum, piperacillin+tazobactum, imipenem, meropenem, colistin, vancomycin, linezolid, erythromycin, clindamycin and gentamycin

\section{RESULTS}

Superficial pus culture was positive in $98 \%$ of samples whereas deep culture was positive in $66 \%$ samples and negative in $34 \%$ i.e there was no growth.

Table 2: Bacteriological isolate from superficial pus culture.

\begin{tabular}{|lll|}
\hline Organism & Number & Percentage \\
\hline Staphylococcus aureus & 21 & $42 \%$ \\
\hline Pseudomonas aeruginosa & 14 & $28 \%$ \\
\hline Streptococcus & 9 & $18 \%$ \\
\hline E. coli & 7 & $14 \%$ \\
\hline $\begin{array}{l}\text { Coagulase negative } \\
\text { staphylococcus }\end{array}$ & 4 & $8 \%$ \\
\hline Klebsiella pneumonia & 4 & $8 \%$ \\
\hline Acinetobacterbaumannii & 1 & $2 \%$ \\
\hline Proteus mirabilis & 1 & $2 \%$ \\
\hline Providenciarettgeri & 1 & $2 \%$ \\
\hline No growth & 1 & $2 \%$ \\
\hline
\end{tabular}

In bacteriological analysis of superficial pus culture (Table 2) it was found that staphylococcus aureus 21 (42\%) was the predominant species isolated followed by pseudomonas in 14 (28\%) of patients, Streptococcus in 9 (18\%) and E. coli in 7 (14\%).

Table 3: Pattern of isolates found in superficial pus culture and deep tissue culture.

\begin{tabular}{|llll|}
\hline $\begin{array}{l}\text { Type of } \\
\text { culture }\end{array}$ & Monomicrobial & Polymicrobial & $\begin{array}{l}\text { No } \\
\text { growth }\end{array}$ \\
\hline $\begin{array}{l}\text { Superficial } \\
\text { pus culture }\end{array}$ & $38(76 \%)$ & $11(22 \%)$ & $1(2 \%)$ \\
\hline $\begin{array}{l}\text { Deep tissue } \\
\text { culture }\end{array}$ & $29(58 \%)$ & $4(8 \%)$ & $17(34 \%)$ \\
\hline
\end{tabular}

It was found that $11(22 \%)$ samples showed more than one isolates, mostly two species were isolated but 38 $(76 \%)$ showed single isolate only. It was found that gram +ve and gram -ve strains were isolated in equal numbers.
As 34 out of 62 isolates were gram +ve while 28 were gram -ve strains.

Table 4: Gram +ve and gram negative isolates found in superficial and deep culture.

\begin{tabular}{|llll|}
\hline $\begin{array}{l}\text { Type of } \\
\text { culture }\end{array}$ & Gram +ve & Gram -ve & $\begin{array}{l}\text { Total number } \\
\text { of isolates }\end{array}$ \\
\hline $\begin{array}{l}\text { Superficial } \\
\text { pus culture }\end{array}$ & 34 & 28 & 62 \\
\hline $\begin{array}{l}\text { Deep tissue } \\
\text { culture }\end{array}$ & 3 & 34 & 37 \\
\hline
\end{tabular}

Table 5: Bacteriological isolates from deep tissue culture.

\begin{tabular}{|lll|}
\hline Organism & Number & Percentage \\
\hline Pseudomonas aeruginosa & 14 & $28 \%$ \\
\hline Klebsiella pneumonia & 9 & $18 \%$ \\
\hline Acinetobacter baumannii & 6 & $12 \%$ \\
\hline E. Coli & 3 & $6 \%$ \\
\hline Staphylococcus aureus & 2 & $4 \%$ \\
\hline $\begin{array}{l}\text { Coagulase negative } \\
\text { staphylococcus }\end{array}$ & 1 & $2 \%$ \\
\hline Proteus mirabilis & 1 & $2 \%$ \\
\hline Proteus vulgaris & 1 & $2 \%$ \\
\hline No growth & 17 & $34 \%$ \\
\hline
\end{tabular}

In bacteriological analysis of deep tissue culture (Table 5) it was found that there was no growth in 17 (34\%) specimen. Pseudomonas was isolated in 14 (28\%), Klebsiella in 9 (18\%), Acinetobacter in $6(12 \%)$ and $E$. coli in $3(6 \%)$. Further analysis showed that 34 isolates out of 37 were gram -ive whereas only 3 were gram +ive. This is remarkable predominance of gram -ive infection in deep tissue culture. Here 4 samples revealed two species whereas 29 samples revealed single species only.

Table 6: Comparative analysis of superficial pus culture and deep tissue culture.

\begin{tabular}{|ll|l|}
\hline Type of growth & Number of cases & Percentage (\%) \\
\hline Similar & 7 & $14 \%$ \\
\hline Different & 18 & $36 \%$ \\
\hline Mixed & 25 & $50 \%$ \\
\hline
\end{tabular}

In $14 \%$ of pressure ulcers the bacteriological pattern of superficial pus culture and deep tissue culture (Table 6) were similar. In $36 \%$ of pressure ulcer, superficial pus culture and deep tissue culture (Table 6) had different isolates. In $50 \%$ of pressure ulcers it was seen that the microbiological isolate from superficial pus culture and deep tissue culture had mixed pattern (comprising of either multiple organisms or no growth in either of culture).

It was found that Staphylococcus aureus was sensitive to vancomycin $(100 \%)$ and linezolid $(95.6 \%)$. Coagulase negative staphylococcus was sensitive to linezolid 
(100\%). It was also sensitive to vancomycin $(80 \%)$ and clindamycin (80\%). Pseudomonas aeruginosa was sensitive to imipenem $(75 \%)$, amikacin $(71.4 \%)$, colisitin $(67.85 \%)$, meropenem (57.2\%) and levofloxacin (42.8\%). Klebsiella pneumoniae was sensitive amikacin (100\%), colistin $(92.3 \%)$, imipenem $(84.6 \%)$, piperacillin + tazobactum $(84.6 \%)$ and gentamicin $(61.5 \%)$. E. coli was sensitive to colistin (100\%), linezolid (100\%), amikacin (80\%), gentamicin (80\%) and imipenem (80\%). Streptococcus was sensitive to linezolid (88.9\%), ampicillin (88.9\%) and vancomycin (77.8\%). acinetobacter baumannii was sensitive to colistin $(85.71 \%)$, imipenem $(85.71 \%)$, amikacin $(85.71 \%)$ and gentamycin $(85.71 \%)$.

Table 7: Organism wise sensitivity of various drugs (superficial + deep tissue culture).

\begin{tabular}{|c|c|c|c|c|c|c|c|c|c|c|c|c|c|c|c|c|c|}
\hline Organism & $\dot{\mathrm{z}}$ & 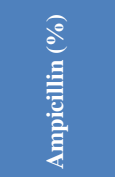 & $\begin{array}{l}\frac{\pi}{3} \\
\frac{\mathrm{g}}{\mathrm{E}} \\
\frac{\mathrm{z}}{4}\end{array}$ & $\frac{\stackrel{B}{0}}{\frac{e}{8}}$ & 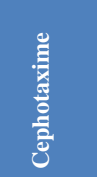 & 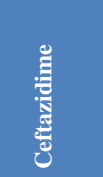 & 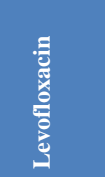 & 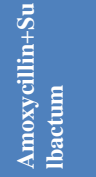 & 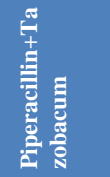 & 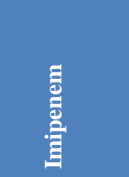 & 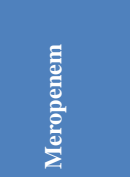 & $\frac{E}{3}$ & $\begin{array}{l}\frac{\Xi}{0} \\
\text { ह } \\
\text { ह } \\
\text { ह }\end{array}$ & 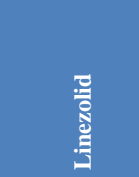 & 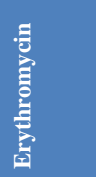 & $\begin{array}{l}\frac{\pi}{0} \\
\frac{E}{E} \\
\frac{\pi}{0} \\
\frac{0}{0}\end{array}$ & 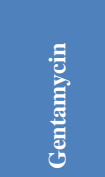 \\
\hline No growth & 18 & - & - & - & - & - & - & - & - & - & - & - & - & - & - & - & - \\
\hline $\begin{array}{l}\text { Pseudomonas } \\
\text { aeruginosa }\end{array}$ & 28 & - & $\begin{array}{l}20 \\
(71.4 \%)\end{array}$ & $\begin{array}{l}10 \\
(35.7 \%)\end{array}$ & $\begin{array}{l}10 \\
(35.7 \%)\end{array}$ & $\begin{array}{l}9 \\
(32.2 \%)\end{array}$ & $\begin{array}{l}12 \\
(42.8 \%)\end{array}$ & $\begin{array}{l}6 \\
(21.4 \%)\end{array}$ & $\begin{array}{l}17 \\
(60.7 \%)\end{array}$ & $\begin{array}{l}21 \\
(75 \%)\end{array}$ & $\begin{array}{l}16 \\
(57.2 \%)\end{array}$ & $\begin{array}{l}19 \\
(67.85 \%)\end{array}$ & - & - & - & - & - \\
\hline $\begin{array}{l}\text { Staphylococcus } \\
\text { aureus }\end{array}$ & 23 & - & - & - & - & - & $\begin{array}{l}16 \\
(69.5 \%)\end{array}$ & - & - & - & - & - & $\begin{array}{l}23 \\
(100 \%)\end{array}$ & $\begin{array}{l}22 \\
(95.6 \%)\end{array}$ & $\begin{array}{l}17 \\
(73.9 \%)\end{array}$ & $\begin{array}{l}19 \\
(82.6 \%)\end{array}$ & $\begin{array}{l}14 \\
(60.8 \%)\end{array}$ \\
\hline $\begin{array}{l}\text { Klebsiella } \\
\text { pneumonia }\end{array}$ & 13 & $\begin{array}{l}4 \\
(30.7 \%)\end{array}$ & $\begin{array}{l}13 \\
(100 \%)\end{array}$ & $\begin{array}{l}0 \\
(0 \%)\end{array}$ & $\begin{array}{l}0 \\
(0 \%)\end{array}$ & $\begin{array}{l}0 \\
(0 \%)\end{array}$ & $\begin{array}{l}1 \\
(7.69 \%)\end{array}$ & $\begin{array}{l}5 \\
(38.5 \%)\end{array}$ & $\begin{array}{l}11 \\
(84.6 \%)\end{array}$ & $\begin{array}{l}11 \\
(84.6 \%)\end{array}$ & $\begin{array}{l}2 \\
(15.4 \%)\end{array}$ & $\begin{array}{l}12 \\
(92.3 \%)\end{array}$ & - & - & - & - & $\begin{array}{l}8 \\
(61.5 \%)\end{array}$ \\
\hline E. coli & 10 & $\begin{array}{l}1 \\
(10.0 \%)\end{array}$ & $\begin{array}{l}8 \\
(80 \%)\end{array}$ & $\begin{array}{l}1 \\
(10 \%)\end{array}$ & $\begin{array}{l}0 \\
(0 \%)\end{array}$ & $\begin{array}{l}0 \\
(0 \%)\end{array}$ & - & - & $\begin{array}{l}8 \\
(80 \%)\end{array}$ & $\begin{array}{l}8 \\
(80 \%)\end{array}$ & $\begin{array}{l}0 \\
(0 \%)\end{array}$ & $\begin{array}{l}10 \\
(100 \%)\end{array}$ & - & $\begin{array}{l}10 \\
(100 \%)\end{array}$ & - & - & $\begin{array}{l}8 \\
(80 \%)\end{array}$ \\
\hline Streptococcus & 9 & $\begin{array}{l}8 \\
(88.9 \%)\end{array}$ & - & - & - & - & - & - & - & - & - & - & $\begin{array}{l}7 \\
(77.8 \%)\end{array}$ & $\begin{array}{l}8 \\
(88.9 \%)\end{array}$ & $\begin{array}{l}0 \\
(0 \%)\end{array}$ & $\begin{array}{l}0 \\
(0 \%)\end{array}$ & $\begin{array}{l}6 \\
(66.7 \%)\end{array}$ \\
\hline $\begin{array}{l}\text { Acinetobacter } \\
\text { baumannii }\end{array}$ & 7 & $\begin{array}{l}2 \\
(28.57 \%)\end{array}$ & $\begin{array}{l}6 \\
(85.71 \%\end{array}$ & $\begin{array}{l}0 \\
(0 \%)\end{array}$ & $\begin{array}{l}0 \\
(0 \%)\end{array}$ & $\begin{array}{l}0 \\
(0 \%)\end{array}$ & $\begin{array}{l}5 \\
(71.42 \%)\end{array}$ & - & $\begin{array}{l}1 \\
(14.28 \%)\end{array}$ & $\begin{array}{l}6 \\
(85.71 \%)\end{array}$ & $\begin{array}{l}4 \\
(57.14 \%)\end{array}$ & $\begin{array}{l}6 \\
(85.71 \%)\end{array}$ & 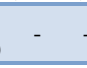 & & - & - & $\begin{array}{l}6 \\
(85.71 \%)\end{array}$ \\
\hline $\begin{array}{l}\text { Coagulase } \\
\text { negative } \\
\text { staphylococcus }\end{array}$ & 5 & - & - & - & - & - & $\begin{array}{l}4 \\
(80 \%)\end{array}$ & - & $\begin{array}{l}0 \\
(0 \%)\end{array}$ & - & - & - & $\begin{array}{l}4 \\
80 \%)\end{array}$ & $\begin{array}{l}5 \\
(100 \%)\end{array}$ & $\begin{array}{l}3 \\
(60 \%)\end{array}$ & $\begin{array}{l}4 \\
(80 \%)\end{array}$ & $\begin{array}{l}4 \\
(80 \%)\end{array}$ \\
\hline $\begin{array}{l}\text { Proteus } \\
\text { mirabilis }\end{array}$ & 2 & - & $\begin{array}{l}2 \\
(100 \%)\end{array}$ & $\begin{array}{l}2 \\
(100 \%)\end{array}$ & $\begin{array}{l}2 \\
(100 \%)\end{array}$ & $\begin{array}{l}2 \\
(100 \%)\end{array}$ & $\begin{array}{l}2 \\
(100 \%)\end{array}$ & - & $\begin{array}{l}2 \\
(100 \%)\end{array}$ & $\begin{array}{l}2 \\
(100 \%)\end{array}$ & $\begin{array}{l}2 \\
(100 \%)\end{array}$ & $\begin{array}{l}1 \\
(50 \%)\end{array}$ & - & - & - & - & - \\
\hline $\begin{array}{l}\text { Proteus } \\
\text { vulgaris }\end{array}$ & 1 & - & $\begin{array}{l}1 \\
(100 \%)\end{array}$ & $\begin{array}{l}0 \\
(0 \%)\end{array}$ & $\begin{array}{l}0 \\
(0 \%)\end{array}$ & $\begin{array}{l}0 \\
(0 \%)\end{array}$ & $\begin{array}{l}0 \\
(0 \%)\end{array}$ & - & $\begin{array}{l}1 \\
(100 \%)\end{array}$ & $\begin{array}{l}1 \\
(100 \%)\end{array}$ & $\begin{array}{l}1 \\
(100 \%)\end{array}$ & $\begin{array}{l}1 \\
(100 \%)\end{array}$ & - & - & - & - & - \\
\hline $\begin{array}{l}\text { Providencia } \\
\text { rettgeri }\end{array}$ & 1 & $\begin{array}{l}0 \\
(0 \%)\end{array}$ & $\begin{array}{l}1 \\
(100 \%)\end{array}$ & $\begin{array}{l}0 \\
(0 \%)\end{array}$ & $\begin{array}{l}0 \\
(0 \%)\end{array}$ & $\begin{array}{l}0 \\
(0 \%)\end{array}$ & $\begin{array}{l}0 \\
(0 \%)\end{array}$ & - & $\begin{array}{l}0 \\
(0 \%)\end{array}$ & $\begin{array}{l}0 \\
(0 \%)\end{array}$ & $\begin{array}{l}0 \\
(0 \%)\end{array}$ & $\begin{array}{l}0 \\
(0 \%)\end{array}$ & - & - & - & - & - \\
\hline Total & & 15 & 51 & 13 & 12 & 11 & 40 & 11 & 40 & 49 & 25 & 49 & 34 & 45 & 20 & 23 & 46 \\
\hline
\end{tabular}

\section{DISCUSSION}

Profitability of specimen sampled in pressure ulcer varies in relation to the site and depth of sample. Moreover it has been shown that proper cleansing of infected site permits the reduction of contaminating cutaneous flora by $90 \%$. $^{3}$ From the superficial swab samples of our pressure ulcers, only one was negative out of fifty samples, which is not surprising as patients were selected for infection of their pressure ulcers. This may have been because of the fact that most of the ulcers were very large in extent and the initial bacterial load was very heavy. As our data suggest that majority of culture positive samples we could identify only one or two isolates per sample, superficial swabs revealed $11(22 \%)$ cases where two species were isolated, whereas in deep tissue culture we were able to get only $4(8 \%)$ cases where two species were grown. This fact supports the hypothesis that there is gross contamination of superficial samples from exogenous source or surroundings. Presence of E. coli, proteus mirabilis in superficial swab samples can be explained by the fact that infection has probably started by colonization of frail skin with bacteria from urogenital or digestive tract. ${ }^{4}$

Gross difference in qualitative analysis between superficial swab and deep tissue culture as detected in our study, where superficial swab were dominantly gram positive strains, where as deep tissue culture were predominantly gram negative strains, can lead to a situation where we are likely to miss the target by initiating therapy on basis of superficial swab results. We are likely to easily miss certain number of species which are responsible for deep tissue infection, leading to a situation of not treating patient correctly as well as for the hospital ecology of selecting antibiotic resistant mutants.

The surgical treatment of infected pressure ulcers by musculocutaneous/fasciocutaneous/ flaps /skin grafting is necessary in most of cases, has to be accompanied by an adequate antibiotic coverage but an emperical antibiotic treatment is difficult to initiate due to large variety of bacterial species involved in such infection, as shown in our study. Thus emperical coverage should not be continued for longer than 3-5 days and must be adapted 
in relation to results of bacteriological investigations. Once the antibiotic treatment can be targeted, it should be continued for 3 weeks if no general symptoms (like fever, osteomyelitis, arthritis, and bacteremia) are present. Otherwise the treatment must be continued up to six weeks. ${ }^{5}$

On bacteriological analysis of superficial pus culture it was found that Staphylococcus aureus $21(42 \%)$ was the predominant species isolated followed by pseudomonas in $14(28 \%)$ of patients. This finding is in agreement with the works of Mohammed et al, Raza MS et al and Mama et al. ${ }^{6-8}$ Staphylococcus was the most common isolate in superficial pus culture. The high prevalence of S. aureus infection may be because it is an endogenous source of infection. Infection with this organism may also be due to contamination from the environment e.g. contamination of surgical instruments. With the disruption of natural skin barrier S. aureus, which is a common bacterium on surfaces, easily find their way into wounds.

In bacteriological analysis of deep tissue culture it was found that there was no growth in 17 (34\%) specimen. Pseudomonas was isolated in $14(28 \%)$ and Klebsiella in $9(18 \%)$.

Comparison of superficial pus culture and deep tissue culture.

In present study we found that superficial pus culture was positive in $98 \%$ of samples whereas deep culture was positive in $66 \%$ samples and negative in $34 \%$ i.e there was no growth. This difference may be because of contamination of the superficial wound from the bacteria over the surrounding skin.

In $34 \%$ of patients there was only superficial infection present as suggested by the superficial pus culture and the deep tissue was sterile as shown in deep tissue culture. This superficial infection can be dealt with dressings and proper hygiene. This superficial infection does not require antibiotics as the part of the treatment. Thus superficial pus culture reports can lead to unnecessary use of antibiotics and this unnecessary use is one of the reasons for increasing drug resistance in the community. Thus deep tissue culture can help in the proper management of the pressure ulcer as well as appropriate use of antibiotics.

In $14 \%$ of pressure ulcers the bacteriological pattern of superficial pus culture and deep tissue culture were similar. In this patients antibiotic can be started based on either of the reports.

In $36 \%$ of pressure ulcer, superficial pus culture and deep tissue culture had different isolates. Among this, in majority of patients the superficial culture showed the growth of staphylococcus aureus and skin contaminants like coagulase negative staphylococcus, whereas the deep tissue culture showed the growth of pseudomonas aeruginosa and klebsiella pneumoniae. Pseudomonas aeruginosa was the predominant isolate in deep tissue culture, this may be because it is a non-fastidious bacteria and it can grow well in moist environment such as of pressure ulcer. It may also be because of nosocomial infection. As in this infective cases if we start antibiotics according to the superficial pus culture it would be inappropriate as this would not cover the bacterial isolates of deep tissue culture which are responsible for infection and thus there may be lack of clinical improvement.

Thus it appears that if we start antibiotics according to superficial pus culture only, it may be an unnecessary, in appropriate or an incomplete drug therapy for the infected pressure ulcer.

The findings were similar to the works of Rudensky B et al, who reported that positive results were obtained for $97 \%$ of cultures of superficial swab specimens compared with $63 \%$ of cultures of deep-tissue biopsy specimens. Concordance was poor between the different bacterial species identified by biopsy and those identified by swab culture. ${ }^{9}$

This finding differed from the work of Slater RA et al who reported that in 37 wounds $(62 \%)$, the microorganism isolated from the swab specimen and those isolated from the deep tissue specimen were identical. ${ }^{10}$

From our study we conclude that results obtained by superficial pus culture did not correlate well with those obtained by deep tissue culture. This suggests that superficial pus culture alone may be less reliable for guiding an antimicrobial therapy.

\section{Antibiotic sensitivity}

Staphylococcus aureus was sensitive to vancomycin (100\%) and linezolid (95.6\%). It was also sensitive to clindamycin (82.6\%), levofloxacin $(69.5 \%)$ and gentamycin $(60.8 \%)$. This finding is in agreement with the work of Mama et al and Raza et al. ${ }^{7,8}$ Remarkable susceptibility of gram positive bacteria to vancomycin may be due to lesser use of these antibiotics as a result of their less availability and cost.

Pseudomonas aeruginosa was one of the predominant isolate but was resistant to most of the antibiotics. Pseudomonas was sensitive to imipenem (75\%), amikacin (71.4\%) and colisitin (67.85\%).This results were in agreement with the work of Raza et al, Pondei et al and Mama et al. ${ }^{7,8,11}$

E. coli was sensitive to colistin (100\%), linezolid (100\%), amikacin $(80 \%)$ and gentamycin $(80 \%)$. This result differed with the work of Mama et al who concluded that gentamycin was $51.7 \%$ sensitive. $^{8}$ 
Limitation of our study was that we did not include the colony count of the bacteria in our study as it would have helped us in making decision for the skin grafting/flap. Anaerobic culture and blood culture were another limitation of the study as it would also have helped in starting the appropriate antibiotics in patients with septicaemia. Follow up culture after giving a course of an appropriate antibiotic could have been considered in our study as it would have helped in determining the efficacy of the antibiotic.

\section{CONCLUSION}

There is a substantial difference between sensitivity pattern of superficial pus culture and deep tissue culture. In the present scenario, culture and sensitivity report of both levels will definitely help in evolving a pattern for initiation of antibiotic therapy. It is not a costly investigation and thus the patient can afford it, so as to avoid unnecessary expenses on costly antibiotics which may not be effective.

Antimicrobial resistance is of particular concern because the problem is widespread, the causative factors are uncontrolled, and national strategies to address the problem are lacking. The persisting burden of infectious diseases makes elimination of antibiotic use unethical, but dramatic overuse and misuse of antimicrobial agents around the world must be reduced to extend the useful lifetimes of these drugs 12. Thus by using proper antibiotics at appropriate time the growing incidence of antibiotic resistance in bacterial population can be prevented to an extent.

Funding: No funding sources Conflict of interest: None declared

Ethical approval: The study was approved by the institutional ethics committee

\section{REFERENCES}

1. Allman RM. Pressure ulcer prevalence, incidence, risk factors, and impact. Clin Geriatr Med. 1997;13:421-37.

2. The National pressure ulcer advisory panel (NPUAP) serves as the authoritative voice for improved patient outcomes in pressure ulcer prevention and treatment through public policy, education and research. Available at www.npuap.org/resources/educational-and-clinicalresources/npuap-pressure-ulcer-stages categories.

3. Rubayi S. Wound management in spinal infection. Orthop clin north am. 1996;27:137-53.

4. Montgomerie JZ. Infection in patients with spinal cord injuries. Clin Infect Dis. 1997;25:1285-92.

5. Mylotte JM, Kahler L, Graham R. Young L, Goodnough S. Prospective survilliance for antibiotic resistant organisms in patients with spinal cord injury admitted to an acute rehabilitation unit. Am J infect contr. 2000;28:291-7.

6. Mohammed A, Adeshina GO, Ibrahim YK. Incidence and antibiotic susceptibility pattern of bacterial isolates from wound infections in a tertiary hospital in Nigeria. Tropical Journal of Pharmaceutical Research. 2013;12(4):617-21.

7. Raza MS, Chander A, Ranabhat A. Antimicrobial susceptibility patterns of the bacterial isolates in post-operative wound infections in a tertiary care hospital, Kathmandu, Nepal. Open Journal of Medical Microbiology. 2013;3:159-63.

8. Mama M, Abdissa A, Sewunet T. Antimicrobial susceptibility pattern of bacterial isolates from wound infection and their sensitivity to alternative topical agents at Jimma University Specialized Hospital, South-West Ethiopia. Ann Clin Microbiol Antimicrob. 2014;13:14.

9. Rudensky B, Lipschits M, Isaacsohn M, Sonnenblick M. Infected pressure sores: comparison of methods for bacterial identification. South Med J. 1992;85:901-3.

10. Slater RA, Lazarovitch T, Boldur I, Ramot Y, Buchs A, Weiss M, et al. Swab cultures accurately identify bacterial pathogens in diabetic foot wounds not involving bone. Diabetic medicine. 2004;2(7):7059,

11. Pondei K, Fente BG, Oladapo O. Current microbial isolates from wound swabs, their culture and sensitivity pattern at the Niger Delta University Teaching Hospital, Okolobiri, Nigeria. Trop Med Health. 2013;41(2):49-53.

12. Mah MW, Memish ZA. Antibiotic resistance. An impending crisis. Saudi Med J. 2000;21(12):1125-9.

Cite this article as: Lunawat A, Vashistha RK, Patidar H, Patel V. Current trend of bacteriological sensitivity patterns from superficial and deep wounds in pressure ulcers. Int Surg J 2016;3:1414-9. 